\section{Dioxin lawsuits}

\section{Agent Orange in the courts}

\section{Washington}

AN attempt by the American Medical Association (AMA) to calm public fears about the health effects of dioxin appeared to backfire last week when an AMA spokesman was forced to admit in a congressional hearing that a resolution dismissing its dangers had been "imprudent"'. The resolution, adopted two weeks ago by the association's House of Delegates, had accused the media of launching an irrational "witch hunt" against dioxin and said the substance appeared to pose no serious health risk to humans.

Dr John Beljan, an AMA spokesman, said that while the resolution had been poorly worded, AMA stood by its claim that there was still little evidence to support allegations that exposure to dioxin had been responsible for the widespread health defects attributed to it. AMA intends to publish later this year a report summarizing the state of the scientific evidence.

An estimated 65 federally-funded dioxin studies are now in progress, but their findings are not expected to receive a dispassionate reception. The scientific evidence is being rapidly converted into legal evidence as part of an emotive confrontation between some 15,000 Vietnam veterans and the chemical companies that manufactured Agent Orange, the herbicide used as a defoliant during the Vietnam war.

The veterans blame dioxin within 2,4,5- $T$ (a component of Agent Orange) for a variety of illnesses including cancers and birth defects. They are suing the chemical industry for damages that could cost hundreds of millions of dollars if the court agrees to treat the case as a classaction suit. In that case, all 2.5 million veterans and their families could claim compensation for health defects they attribute to Agent Orange.

A trial scheduled to begin last week has been postponed for at least another year to give the veterans and the chemical companies time to accumulate more evidence. Papers already filed by the veterans have been sealed by the New York court hearing the case, but enough details have been leaked to make it clear that some of the manufacturers were aware of the health risks of 2,4,5-T several years before spraying with Agent Orange ended in 1970.

How much the chemical companies knew about dioxin contamination when they manufactured Agent Orange has become a key issue since the companies being sued decided to make a "government contractor defence". If the companies can prove that the federal government knew as much about dioxin as the manufacturers, and that Agent Orange was manufactured to government specifications, the companies will be covered by federal immunity from liability,

Arguments at the trial will therefore con- centrate on two issues: did the chemical companies suppress their knowledge about dioxin contamination in Agent Orange in order to protect the lucrative $2,4,5-\mathrm{T}$ industry; and can exposure to Agent Orange have caused the wide range of health defects which the veterans ascribe to it?

Leaked correspondence between the chemical companies suggests that at least one manufacturer, Dow Chemical Company, was sufficiently worried in 1965

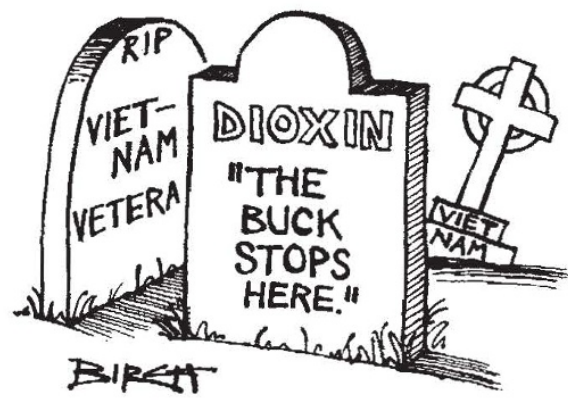

about the high levels of dioxin to have summoned its competitors to a meeting to share its findings.

The decision to postpone the trial for at least another year means the court will have access to considerably more scientific evidence. And judging by the reception last week of the first Agent Orange study, the scientific evidence will be as contentious as the question of liability. Mr Victor Yannacone, who initiated the veterans' action against the companies, dismissed as "worthless" the finding of an Air Force study of more than 1,200 personnel who had been directly involved in the "Ranch Hand"

operation during which Agent Orange was sprayed from US aircraft.

Dr Alvin Young, an Air Force medical adviser, said a mortality study had revealed no difference in the death rate of Ranch Hand personnel and other veterans who had not been exposed to the herbicide. Although Ranch Hand personnel handled large quantities of Agent Orange without wearing protective clothing, only four deaths from cancer had occurred and there were no reports of soft-tissue tumours. Yannacone claimed that the Ranch Hand study was statistically inconsequential.

In congressional evidence last month, however, the Veterans Administration deputy chief medical director, Dr William Jacoby, said he was confident that the range of studies now under way would provide "scientifically acceptable answers" about the health effects of Agent Orange. He cited eight major investigations that are expected to yield results within the next year. They include a mortality study of 60,000 deceased veterans, a study of identical twins where only one brother served in Vietnam and an investigation of a possible link between service in Vietnam and softtissue sarcomas.

Although the Veterans Administration is leading the federal research effort in Agent Orange, it is regarded with suspicion by many veterans because it is also the agency that would be responsible for compensating victims of service-related illnesses. Bowing to pressure from veterans, Congress has directed that a major epidemiological study of Agent Orange be transferred to the Centers for Disease Control, Atlanta which are also conducting a study of birth defects in the children of Vietnam veterans, with publication expected early next year.

Peter David

\title{
Ne'eman's too broad Israeli horizon
}

ISRAEL. could be short of 5,000 engineers and 8,000 engineering technicians by 1992 , according to Dr Yuval Ne'eman, the minister of science and research.

Reporting on his ministry's first year of activity, Dr Ne'eman told the Knesset last month that the expected shortfall in the training of engineers could seriously delay Israeli plans to develop science-based industry. The main problem, he said, is a lack of lecturers, with even such a prominent institution as the Technion having difficulty in filling all its appointments.

Science-based industry is widely acclaimed as Israel's key to future prosperity, although Dr Ne'eman himself believes that in the long run it will be the export of knowhow rather than of technology that will become increasingly important. He is a keen supporter of the proposal to develop "Region 2000", the projected "science area" to be based on Karmiel in north-west Galilee, which would create an estimated 10,000 jobs in high-technology industries and perhaps another 10,000 in other sectors.

The official proposals from the ministry for trade and industry for Region 2000 stressed that it should "promote constructive coexistence"' between Jews and Arabs in the area, "to the benefit of both communities and without the strains caused by competition for available arable land". Dr Ne'eman, however, is well known for his "hawkish" politics, and in the debate on his minister's report was attacked for supporting schemes over which public opinion is, to say the least, divided. These include plans for science cities at Ariel (Samaria), Katzim (on the Golan Heights), Kryat Arba (Hebron) and also the southern route for the Mediterranean-Dead Sea canal, crossing the Gaza Strip. According to Mr Shevah Weiss of the (opposition) Alignment, no fewer than 8 of the 14 projects emphasized by Dr Ne'eman involved sites outside the pre-1967 frontiers.

Vera Rich 